\title{
'THE RESEARCH SAYS ...': PERCEPTIONS ON THE USE OF SOCIAL SCIENCE RESEARCH IN THE FAMILY LAW SYSTEM
}

\author{
Zoe Rathus*
}

\begin{abstract}
This article reports on a study which investigated the perceptions of professionals in the family law system about how social science research is used in that system in Australia. The results shed light on the daily practices of actors in the system regarding their use of social science research and demonstrate the ubiquitous presence of this research in the family law environment. The study involved a series of focus groups with lawyers and social scientists and gathered data about how the participants perceived various professions engaged with social science research. This revealed the actual world of family law practice, undiscoverable from the published cases. The data show how practitioners perceive that family law professionals, including judges, harness the research positively, but also expose a range of concerns, particularly about judges citing social science research in the courtroom. The article concludes with some steps that could be taken to clarify the way in which social science research could be used.
\end{abstract}

\section{INTRODUCTION}

This article reports on a study of the perceptions of Australian family law professionals about how social science research was employed in the family law system at a time when judicial citation of social science literature in published decisions reached a peak. ${ }^{1}$ This coincided with amendments to the Family Law Act 1975 (Cth) ('Act') that encouraged post-separation shared parenting arrangements. The way in which social science research is used in the family law system is a matter of considerable national and international interest. ${ }^{2}$ It also opens a window into the wider question of the use in

* Senior Lecturer, Griffith University Law School. Many friends and colleagues have assisted me in the preparation and presentation of this article. I wish to express my thanks to everyone, and in particular, Mary Keyes, Kylie Burns, Richard Chisholm, April Chrzanowski, Heather Douglas, Samantha Jeffries and Laura Robertson.

1 Zoe Rathus, 'Mapping the Use of Social Science in Australian Courts: The Example of Family Law Children's Cases' (2016) 25 Griffith Law Review 352. A peak was reached in the period from 2006-12 and the focus groups were held in 2012 and 2013.

2 See, eg, Alan Hayes, 'Social Science and Family Law: From Fallacies and Fads to the Facts of the Matter' in A Hayes and D Higgins (eds), Families, Policy and the Law: Selected Essays on Contemporary Issues for Australia (Australian Institute of Family Studies, 2014) 283; Judith Cashmore and Patrick Parkinson, 'The Use and Abuse of Social Science Research Evidence 
courtrooms of 'outside' knowledge -ie knowledge that is non-legal in nature and is not part of the evidence of the parties-another matter of interest to the broader legal community. ${ }^{3}$

Social science research has underscored family law policy since the creation of the Family Court of Australia and the commencement of the Act in 1976. Despite this, the engagement with this research by practitioners and judges in the family law system has been given little research attention in Australia. ${ }^{4}$ Perhaps because social science research has been a kind of 'surround-sound' in family law, professionals in that system hardly notice its presence as a distinct discipline within a legal space. While social science content is regularly presented at family law conferences and in journals, there is little consideration about how the research is used and whether it is used appropriately. The purpose of the study presented in this article was to shed light on the actual practices of actors in the system to create a picture of how social science research is used.

The research involved focus groups with professionals, from a range of disciplines, who practise in the family law system; lawyers, family dispute resolution practitioners

in Children's Cases' (2014) 20 Psychology, Public Policy, and Law 239; Karen Broadhurst et al, Towards a Family Justice Observatory - A Scoping Study: Main Findings Report of the National Stakeholder Consultation (2017) <http:/ / wp.lancs.ac.uk/observatory-scopingstudy / files / 2017/08/National-Stakeholder-Consultation-Main-Findings-Report.pdf>; Baroness Hale, 'Should Judges be Socio-Legal Scholars?' (Speech delivered at the SocioLegal Studies Association Conference, University of York, 26 March 2013) <https://www.supremecourt.uk/docs/speech-130326.pdf>; Irwin Sandler et al, 'Convenient and Inconvenient Truths in Family Law: Preventing Scholar-Advocacy Bias in the Use of Social Science Research for Public Policy' (2016) 54 Family Court Review 150; Richard A Warshak, 'Social Science and Parenting Plans for Young Children: A Consensus Report' (2014) 20 Psychology, Public Policy, and Law, 46; Sarah H Ramsey and Robert F Kelly, 'Social Science Knowledge in Family Law Cases: Judicial Gatekeeping in the Daubert Era' (2004) 59 University of Miami Law Review 1.

3 See, eg, Kylie Burns, Rachel Dioso-Villa and Zoe Rathus, 'Judicial Decision-Making and "Outside" Extra-Legal Knowledge: Breaking Down Silos' (2016) 25 Griffith Law Reviezw 283; Gary Edmond, David Hamer and Emma Cunliffe, 'A Little Ignorance Is a Dangerous Thing Engaging with Exogenous Knowledge Not Adduced by the Parties' (2016) 25 Griffith Law Review 383; Andrew Serpell, 'Social Policy Information: Recent Decisions of the High Court of Australia' (2011) 21 Journal of Judicial Administration 109; Russell Smyth, 'Academic Writing and the Courts: A Quantitative Study of the Influence of Legal and Non-Legal Periodicals in the High Court' (1998) 17 University of Tasmania Law Review 164; Ivo Giesen, 'The Use and Incorporation of Extralegal Insights in Legal Reasoning' (2015) 11 Utrecht Law Review, 1; Allison Orr Larsen, 'Confronting Supreme Court Fact-Finding' (2012) 98 Virginia Law Review 1255.

4 There are some exceptions. See, eg, Tom Altobelli, 'The Effective Use of Social Science Research in Family Law in Australia' (Paper Presented at $12^{\text {th }}$ National Family Law Conference, Perth, 2006) 125; Richard Chisholm, 'Risks in Using Social Science Publications' (2012) 26 Australian Journal of Family Law 78. Research has been undertaken in the USA since the 1940s. See, eg, Kenneth Culp Davis, 'An Approach to Problems of Evidence in the Administrative Process' (1942) 55 Harvard Law Review 364; Peggy C Davis, "There is a Book Out ...": An Analysis of Judicial Absorption of Legislative Facts' (1987) 100 Harvard Law Review 153; Laurens Walker and John Monahan, 'Social Frameworks: A New Use of Social Science in Law' (1987) 73 Virginia Law Review 559. 
(FDRPs), ${ }^{5}$ family consultants ${ }^{6}$ and counsellors. The discussions canvassed how the various professions used social science research in their practices as well as their perceptions of how judges were using such research in the family courts. ${ }^{7}$ This allowed for exploration of how social science has entered the daily work of practitioners and judges, and provided an opportunity to understand the intersection of these disciplines in ways undiscoverable through published cases.

Section II of this article describes the background and impetus for the research and Section III sets out the methodology employed. Section IV presents the findings of the study. It outlines some overall findings that provide a context for the rest of the data and then discusses key findings in respect of various actors - judges, legal practitioners and social scientists. Although it was clear from the focus groups that knowledge of social science research is a critical part of the tool kit of practitioners of all kinds, apprehension was expressed about judges drawing directly from social science literature in their decision-making. Section $V$ considers the significance of the findings and makes some tentative suggestions for further research and future directions.

\section{BACKGROUND}

Given the obvious interplay between the disciplines of social science and law in the family law space, there is surprisingly little research which investigates the use of social science research by professionals (other than judges) in that system. Some research has been conducted into the relationships across disciplines ${ }^{8}$ and the ways in which lawyers and other professionals deal with concepts which are informed by the social sciences. These include what is meant by the 'best interests of the child', ${ }^{9}$ how to be child focused, ${ }^{10}$ and how the parenting provisions of the Act could be improved to make them more responsive to children's developmental needs. ${ }^{11}$ But no prior Australian research has directly asked professionals in the system for their views about how their work and the work of other actors are actually informed by social science research.

Social science research has in fact been deeply embedded in policy, legislative development, the operation of the courts and the practices of all of the professional groups in family law from the start of the modern family law system in the mid-1970's. The original Act heralded a new era in divorce-allowing a shift from the indignity of matrimonial fault to a more sympathetic approach. With the benefit of hindsight, the

5 Who used to be known as 'mediators'.

6 Social scientists involved in counselling as well as forensic report writing. See Act s 11B for definition.

7 In this article 'family courts' mean the Family Court of Australia and the Federal Circuit Court of Australia (which was known as the Federal Magistrates Court until 2013.

8 See, eg, H Rhoades et al, Enhancing Inter-Professional Relationships in a Changing Family Law System: Final Report (University of Melbourne, 2008).

9 Antoinette L Harmer and Jane Goodman-Delahunty, 'Practitioners' Opinions of Best Interests of the Child in Australian Legislation' (2014) 21 Psychiatry, Psychology and Law 251.

10 Cate Banks, 'Being a Family Lawyer and Being Child Focused: A Question of Priorities' (2007) 21 Australian Journal of Family Law 37.

11 Helen Rhoades, Grania Sheehan and John Dewar, 'Developing a Consistent Message about Children's Care Needs across the Family Law System' (2013) 27 Australian Journal of Family Law 191. 
Family Court of Australia has been described as an early form of 'therapeutic' justice, ${ }^{12}$ with a built-in counselling section ${ }^{13}$ and a 'clear intent to synthesise behavioural sciences and law to promote the psychological functioning of separating and separated couples in ways that promote their, and their children's, interests'. ${ }^{14}$

In documenting some of the early history of the Family Court of Australia Helen Rhoades and Shurlee Swain report that, after the commencement of the new court, legal practitioners started to realise that they had to learn something about social science research. As one lawyer, who was practising family law at that time, said when he was interviewed:

[The legal profession] ... had to start embracing the social sciences in a real way, which we really hadn't done before. So I remember thinking 'I've got to get on top of psychology here in terms of relationships and things', so it became a self-education thing. It was just something you'd never had to think about previously. ${ }^{15}$

There is some Australian literature which addresses the use of social science research by family law judges. ${ }^{16}$ The first investigation of this issue was conducted in 1998 by Graham Mullane when he was a sitting judge of the Family Court of Australia. The scope of his research was broader than social science literature and examined the use by judges of 'social facts'. ${ }^{17}$ He defined 'social facts' as 'facts concerning human behaviour. ... facts revealed by the disciplines of history, psychology, sociology, anthropology, political science and related fields. ${ }^{\prime 18}$ Mullane sought to identify the basis for findings of social fact made by the court and undertook a survey of all of the final custody judgments in contested cases heard by the Family Court around Australia for the year 1990. The survey revealed that there was one or more finding of social fact in $30 \%$ of the cases. In $60 \%$ of those cases no source was stated for the social fact. In only $1 \%$ of cases was the

12 Chief Justice Diana Bryant and Deputy Chief Justice John Faulks, 'The 'Helping Court' Comes Full Circle: The Application and Use of Therapeutic Jurisprudence in the Family Court of Australia'(Paper presented at $3^{\text {rd }}$ International Conference of Therapeutic Jurisprudence, Australian Institute of Judicial Administration, Perth, 2006); Chief Justice Diana Bryant and Deputy Chief Justice John Faulks, "The "Helping Court" Comes Full Circle: The Application and Use of Therapeutic Jurisprudence in the Family Court of Australia' (2007) 17 Journal of Judicial Administration 93; Helen Rhoades, 'The "Helping Court" $^{\prime \prime}$ : Exploring the Therapeutic Justice Origins of the Family Court of Australia (2011) 2 Family Law Review 17.

13 A Marshall, 'Social Workers and Psychologists as Family Court Counsellors within the Family Court of Australia' (1977) 30(1) Australian Social Work 9.

14 Bryant and Faulks, above n 12, 8.

15 Helen Rhoades and Shurlee Swain, 'A Bold Experiment? Reflections on the Early History of the Family Court' (2011) 22 Australian Family Lawyer 11, 18, quoting Brisbane lawyer Peter Sheehy - who is still working in the field of family law. See Australian Institute of Family Law Arbitrators and Mediators, Peter Sheehy< http://www.aiflam.org.au/Peter-Sheehy295>.

16 Altobelli, above $\mathrm{n}$ 4; Chisholm, above $\mathrm{n} 4$.

17 Graham R Mullane, 'Evidence of Social Science Research: Law, Practice, and Options in the Family Court of Australia' (1998) 72 Australian Law Journal 434.

18 Ibid 434. Some examples of social fact include: 'a "father figure" is often very important in setting down moral values and moral systems ... often the mother is a little less so' and ' $[t]$ he vast majority of the children of drug addicts do not themselves become drug users': at 457. 
'research nominated by the judge and specified in the judgment'. ${ }^{19}$ Mullane also identified a group (5\%) where the source was described as "'research" but [the] judge did not identify the research' ${ }^{20}$

A study which mapped a history of citations of social science literature in published family law judgments demonstrates that such material has been cited by judges since the first year of operation of the Family Court of Australia in 1976 and has continued to varying degrees until the present. ${ }^{21}$ That research showed that the literature cited by judges often reflected the social science contemporaneously in vogue in the wider family law community. It also showed that other actors in the family law system-lawyers, expert witnesses and litigants (either directly or through their lawyers)-were citing some of the same social science in the courts. However, there was a quantum leap in judicial referencing of social science in published cases between 2006 and 2012 until the case of McGregor, which effectively prohibited judicial citation of social science. ${ }^{22}$ This surge in engagement with social science research in judicial decisions coincided with amendments that brought about a presumption that equal shared parental responsibility is in the best interests of children ${ }^{23}$ and encouraged post-separation shared parenting time, but provided little guidance about when such an arrangement might work well. ${ }^{24}$ After the 2006 amendments, judges tended to cite research that reported on studies regarding shared care of children after parental separation when the children were very young or when there were high levels of parental conflict. This suggested that judges were seeking to plug gaps in the legislation. 25

Whether cause or effect, as judicial citation continued to increase, papers which provided ideas about how lawyers could make strategic use of social science literature

19 Ibid 453.

20 Ibid.

21 Rathus, 'Mapping the Use of Social Science', above $\mathrm{n} 1$.

22 McGregor v McGregor (2012) 47 Fam LR 498 ('McGregor'). Barrister Michael Kearney SC draws a link between the 'marked resurgence in explicit reference to and reliance upon such material in judgments' and the publication of particular research in 2007 and 2008 which related directly to the 2006 amendments. See M Kearney, 'The Scientists are Coming: What Are the Courts to Do with Social Science Research?' in A Hayes and D Higgins (eds), Families, Policy and the Law: Selected Essays on Contemporary Issues for Australia (Australian Institute of Family Studies, 2014) 275, 277. He noted the following articles as relevant: Richard Chisholm and Jennifer McIntosh, 'Shared Care and Children's Best Interests in Conflicted Separation: A Cautionary Tale from Current Research' (2007) 20 Australian Family Lawyer 3; A Tucker, 'Shared Parenting - Public Perceptions vs Legislative Reality: Our Role in Making it Work for Children' (Paper presented at 13' National Family Law Conference: Families: Broken Blended Mended, Adelaide, 2008).

23 Act s 61DA.

24 The amendments specifically require consideration of equal time and 'substantial and significant' time orders where an order for equal shared parental responsibility has been made. See Act s 65DAA; Goode v Goode (2006) 36 Fam LR 422. This decision was critiqued by Renata Alexander and Zoe Rathus in Renata Alexander and Zoe Rathus, 'Goode and Goode' in Ann Genovese, 'Goode and Goode: The Practise of Feminist Judgment in Family Law' in Heather Douglas et al (eds), The Australian Feminist Judgments Project: Righting and ReWriting Law (Hart Publishing, 2014) 379, 383.

25 Rathus, 'Mapping the Use of Social Science', above n 1, 370. 
in arguing their cases started to be presented at practitioner conferences. ${ }^{26}$ They painted a multi-layered picture of the benefits, uses and possible abuses that occur by positioning social science literature in a courtroom along-side the evidence of the parties and other witnesses-lay and expert. Where the use of social science research by judges has been critically examined by Australian scholars, practitioners and the judiciary (extra-curially), concern has been expressed about a range of issues which include:

- the fact that there is no legal basis by which judges can introduce social scientific research because such material does not fall within the parameters of $s 144$ of the Evidence Act 1995 (Cth) or judicial notice; ${ }^{27}$

- if such material is introduced at the time of delivering judgment, natural justice has not been afforded to the parties; ${ }^{28}$

- social science is nearly always contested;29

- assessing the 'validity and value' of social science research is likely to be 'unfamiliar and uncomfortable territory for lawyers untrained in empirical research'; 30

- there are risks of selectiveness - looking only at a small number of studies and 'overlooking the caveats and concerns that apply to them'; $; 1$ and

- there are risks that judges might apply 'group data to individual instances'. ${ }^{32}$

The focus group research explored how professionals engaged in the system spoke about their own use of social science and how they perceived others engaged with this extra-legal body of knowledge.

\section{METHODOLOGY}

The aim of this study was to investigate how lawyers, FDRPs, family consultants and counsellors themselves spoke about and used social science research and how they perceived how others used it. Focus groups were chosen as the method of data collection because they allow for a wide-ranging investigation of issues and experiences which can be useful at an exploratory stage. ${ }^{33}$ They facilitated the collection of detailed information

26 Women's Legal Services NSW, 'How to Win Cases and Influence Judges: Using Social Science Research in Family Law Matters' (Paper presented at National Association of Community Legal Centres Conference, Perth, 2009); N Wilson, 'Using the Research Persuasively: How to Apply Social Science Research in Practice' (Paper presented at 27th Annual Calabro SV Consulting Family Law Residential, Gold Coast, 2012).

27 Altobelli, above n 4; Chisholm, above n 4; Zoe Rathus, 'A Call for Clarity in the Use of Social Science Research in Family Law Decision-making' (2012) 26 Australian Journal of Family Law 81; The Hon Chief Justice Diana Bryant, 'The Use of Extrinsic Materials - with Particular Reference to Social Science and Family Law Decision Making' (Paper presented at Judicial Conference of Australia Colloquium, Fremantle, 2012).

28 Altobelli, above n 4; Chisholm, above n 4; Rathus, 'A Call for Clarity', above n 27; Bryant, above, $\mathrm{n} 27$.

29 Bryant, 'The Use of Extrinsic Materials', above n 27; Kearney, above n 22.

30 Altobelli, above $n$ 4, 128 .

31 Hayes, above n 2, 292.

32 Ibid 291.

33 Michael Bloor et al, Focus Groups in Social Research (Sage, 2002) 9; David W Stewart, Prem N Shamdasani and Dennis W Rook, Focus Groups: Theory and Practice (Sage, 2007) 41. 
and insights ${ }^{34}$ and consideration of what happens in family law practice beyond the information that can be gleaned by reading published cases. Focus groups present opportunities for participants to comment on, or even challenge, others' ${ }^{\prime}$ perceptions. ${ }^{35}$ In the context of this project, challenges were able to be made to a participants' interpretation of the law and/or approaches to practice.

Five focus groups were conducted during 2012 and 2013 in Brisbane and Cairns respectively. ${ }^{36}$ Three were with groups of lawyers and two were with groups of nonlawyers. ${ }^{37}$ Participants were recruited through a number of different sources including attendees at the Queensland Annual Family Law Residential Conference in 2012,38 the email distribution lists of a range of family law system associations and organisations and professional contacts of the researchers. There were no obvious differences between the experiences of the practitioners geographically, but the lawyer groups and nonlawyer groups offered different insights.

In total, 31 participants attended the focus groups - 21 identified as lawyers and 10 as non-legal professionals. ${ }^{39}$ The lawyers consisted of 16 solicitors and five barristers; seven had less than five years of practice, five had six to ten years, three had eleven to twenty years and six had over twenty years' experience. The non-lawyers comprised six FDRPs, two counsellors and two described as 'other'. The professional qualifications of the non-lawyers were mainly social work and psychology. It is of some note that all of the non-lawyers were over 40 years old and 15 of the 21 lawyers were also in this age group, suggesting a significant level of maturity and experience amongst the participants. ${ }^{40}$ These were professionals who had practised through many changes in the delivery of family law in Australia and were able to bring a significant level of sophistication to the discussions which occurred.

The lawyers and non-lawyers were allocated into separate focus groups because it was anticipated that this would facilitate a more targeted and intense discussion in each group. ${ }^{41}$ To facilitate the group discussion a series of questions and trigger points was prepared but broad-ranging discussion was encouraged. The questions provided a background guide only. They included general questions about social science, explored what the participants read and how they accessed this, how they saw other professionals using social science and how it was used by judges and others in the courtroom. Some questions were also asked about the family violence reforms to the Act which had just

34 See Bruce L. Berg, Qualitative Research Methods for the Social Sciences (Pearson, $5^{\text {th }}$ ed, 2004); David Silverman (ed), Qualitative Research (Sage, 2010); Richard Krueger and Mary Anne

Casey, Focus Groups: A Practical Guide for Applied Research (Sage, 5th ed, 2014).

35 P Kidd and M Parshall, 'Getting the Focus and the Group: Enhancing Analytical Rigor in Focus Group Research' (2000) 10 Qualitative Health Research 293, 294.

36 Three were in Brisbane and two were in Cairns.

37 There was one non-lawyer group in each of Brisbane and Cairns.

38 27th Annual Calabro SV Consulting Family Law Residential, Gold Coast, 2012, hosted by the Queensland Law Society and the Family Law Practitioners Association (Queensland).

39 Some participants fell into more than one category but attended the focus group which related to their main area of practice (eg participants with law degrees who now practised as FDRPs attended as FDRPs.)

40 This age group reflects the demographics of the researchers and the preponderance may have been influenced by their personal and/or professional connections.

41 A level of homogeneity has been described as bringing compatibility and effectiveness to group work. See Stewart, above n 33, 27. 
become operative at the time of the first focus groups. ${ }^{42}$ The discussions were quite animated at times and the fact that the participants in each group shared a professional background enabled the evolution of quite incisive and challenging conversations.

There are limitations to the use of focus groups in research. The facilitator may bias views unwittingly by providing cues or other information. ${ }^{43}$ Also the 'interaction of respondents with one another and with the moderator' means that 'responses from members of the groups are not independent of one another'. ${ }^{44}$ On the other hand, the interaction between the facilitator and the participants 'provides opportunities for the clarification of responses, for follow-up questions, and for the probing of responses. ${ }^{.45}$ Tamara Walsh and Heather Douglas noted in their focus group study about lawyers' role in the child protection system that there were limitations of this method but they considered that this method produced rich data. Such limitations related to answers compounding or participants exaggerating a view because the speaker was responding to group dynamics. ${ }^{46}$ Although the number of participants in the current study was quite small, they were broadly representative of the professionals working in the family law system, they brought significant (as well as varied) years of experience and operated in two distinct geographic locations. The issues discussed were consistent with the limited extant literature and key themes were repeated by the different groups.

Ethical approval was obtained for the conduct of the focus groups, all of which were recorded and subsequently transcribed with the fully informed consent of participants. The recordings were transcribed in a manner that de-identified participants and the transcriptions were then thematically analysed using both inductive and deductive coding. ${ }^{47}$ Inductive coding was utilised because of the dearth of extant literature examining the use of social science research by family law professionals. It was therefore necessary to develop some coding from the ground up as themes emerged from careful reading and re-reading of the transcripts. ${ }^{48}$ Deductive coding was also employed, drawing from the discussion framework, or trigger points, that had been used during the focus group sessions.

42 Family Law Legislation Amendment (Family Violence and Other Matters) Act 2011 (Cth) which become operative on 7 June 2012.

43 Stewart, above $\mathrm{n} 33,43$

44 Ibid.

45 Ibid 42

46 Tamara Walsh and Heather Douglas, 'Lawyers, Advocacy and Child Protection' (2011) 35 Melbourne University Law Review 621, 625.

47 See Elizabeth H Bradley, Leslie A Curry and Kelly J Devers, 'Qualitative Data Analysis for Health Services Research: Developing Taxonomy, Themes, and Theory' (2007) 42 Health Services Research 1758, 1763; Jennifer Fereday and Eimear Muir-Cochrane, 'Demonstrating Rigor Using Thematic Analysis: A Hybrid Approach of Inductive and Deductive Coding and Theme Development' (2006) 5 International Journal of Qualitative Methods 80.

Fereday and Muir-Cochrane, above $\mathbf{n} 47$. This is a kind of 'grounded theory' approach because the theories arose out of the data analysis. See Juliette Corbin and Anselm Strauss, 'Grounded Theory Research: Procedures, Canons and Evaluative Criteria' (1990) 13 Qualitative Sociology 3. 


\section{FOCUS GROUP FINDINGS}

\section{A Introduction}

This section of the article describes and considers the findings of the focus group study. It begins with some overall findings about the presence of social science research in the family law system, what participants thought is meant by 'social science', and the limitations of its availability. It then examines participants' perceptions of how judges, legal practitioners and social scientists use social science literature. It describes participants' perceptions of the variety of ways judges have drawn social science information into their courtrooms, and some of their concerns about this. It also reveals the strategic role played by social science research in the hands of judges, lawyers and social scientists, and considers the importance of transparency when particular concepts lie behind expert opinion.

The period of time during which the focus groups were conducted was a particularly significant time in the use of social science research in the family law system. They took place over 2012-13, six years after the 2006 shared parenting amendments to the Act, and just as the impact of an important appellate decision condemning judicial citation of social science research by the Full Court of the Family Court, McGregor, was taking effect. ${ }^{49}$ This was a high point of judicial referencing of social science research in the courts and a time of animated discussion about post-separation shared parenting in the family law and wider community. The focus group discussions were not restricted to the contemporaneous period, but much of the talk was about the present. Where participants talked about earlier practices they generally identified that they were speaking historically.

In terms of situating the data in the aftermath of McGregor, it is important to note that this research did not scrutinise published judgments - or even unpublished judgments. Rather, it examined all that happens in the family law system that is not in formal reasons for judgments. Overt referencing of social science research in written judgments may have declined since $M c G r e g o r, 50$ but the on-going relationship between social science research and the family law system continues. Social scientists present at family law conferences ${ }^{51}$ and lawyers, counsellors, FDRPs and family consultants work with each other on a daily basis. Family law is inevitably, irrevocably and appropriately interdisciplinary. Although there may have been some ripple effect, what was said in McGregor is unlikely to have unduly impacted the daily work practices described by the participants.

Research conducted in the United Kingdom over 2016-17 returned some similar results in respect of the use of social science research by practitioners. This occurred in the context of a project to investigate the establishment of a Family Justice Observatory as a central repository and dissemination point for family law related research. The research team ${ }^{52}$ consulted throughout the family law community in the UK about their

49 (2012) 47 Fam LR 498.

50 Ibid.

51 For example a number of social scientists are listed on the program for the 2016 Biennial

National Family Law Conference, including family consultants and academic researchers:

Family Law Section, Law Council of Australia, 'Conference Program', $17^{\text {th }}$ National Family

Law Conference, (Melbourne, October 2016).

52 Led by Professor Karen Broadhurst, Professor of Social Work at Lancaster University. 
research needs and priorities and the opportunities and barriers to the application of research evidence in policy and practice'. 53 The data collected in that consultation confirm the tenor of our results, with the family law community there also demonstrating a sound working knowledge of existing social science research, albeit a somewhat limited range. 54

\section{B What is 'Social Science'?}

We were interested to explore what the focus group participants thought was meant by 'social science'. It was an open question early in the discussions in each group. The online Oxford Dictionary definition of social science is: '[t]he scientific study of human society and social relationships". ${ }^{55}$ One lawyer described it as part of her practice framework, a theme that was repeated by many participants:

It's actually a community of practice which informs the way we ... I would hope ... we understand people's behaviour. Clients' behaviour, people who come within our orbit in our legal practice. So it adds another dimension for us in understanding our clients' motivations and behaviours and the implications of the decisions that are made and the process that we're engaged in in various stages.

The social science participants were serious about the importance of social science research to family law practice and valued this knowledge. As one social scientist said:

I think sometimes when that term [social science] is used the emphasis sometimes is on the social whereas - and I think people can devalue the science side of it. I think, for me, this is why I'm here tonight because I really value research. I value the science practitioner. I value the fact that we can evidence what we do and what we tell our clients based on good research. For me, the science side of it is really important.

There was a broad range of views about what might be encompassed and how social science was perceived but there was also an overall consensus that social science research provided useful information for understanding human conduct and relationships and the social context in which people live. The label 'social science' was quite generally applied by our participants to a wide variety of types of material including social scientific articles, socio-legal articles, books, research reports commissioned by government and statistical reports.

\section{Social Science Research is Ubiquitous}

It is apparent from the discussions in the focus groups that the family law system is saturated with social science research and literature at every level in every imaginable form; from brochures for clients at service agencies, 56 to complex reports and scholarly works. Both the legal and social science participants reported that social science research was brought in to them and their colleagues by clients. It had been sourced from the internet, community agencies, magazines and even academic journals. ${ }^{57}$ In turn,

53 Broadhurst et al, above $\mathrm{n} 2,4$. In the UK public law cases (ie child protection) are part of the family law system - so the consultation covered both private and public law.

54 See Kylie Burns, 'Judges, "Common Sense" and Judicial Cognition' (2016) 25 Griffith Law Review 319.

55 Oxford University Press, Definition of Social Science in English, Oxford Dictionaries <http://www.oxforddictionaries.com/definition/english/social-science>.

56 Usually containing summaries of key research.

57 For example, one participant advised that a client had brought in an article by Professor Richard Chisholm. 
practitioners gather social science literature and provide relevant materials to their clients. Solicitors provide articles or more simplified material, FDRP services provide all kinds of social science information in easily digestible forms such as pamphlets and brochures, and judges discuss the research with legal representatives, self-representing litigants and expert witnesses during trials. This was not really surprising. Research published in the United States in 1985 already identified that social science research had penetrated legal culture - but also asserted that 'social science is now deeply embedded in mass culture'. 58

\section{Access is Limited}

An unexpected, although understandable, finding was that some practitioners have quite limited access to the wide range of social science research available. ${ }^{59}$ Many practitioners from across the disciplines cannot afford expensive subscriptions to scholarly journals 60 - or, for lawyers, even the major legal on-line services. Some subscribe to a key service or journal but most have no easy access to the vast body of social science research published in academic journals. Many rely on attending professional conferences, the internet and professional association email lists which disseminate information useful to their membership. Some small legal firms have an incentive to employ law students in their offices because this provides informal access to the student's university library materials!

The issue of limited access was captured by one social science participant who explained:

I was working for the court, which meant I had access to all that lovely - the library, the

librarian, you'd just ring up and say what have you got on this subject, and you'd get all

the books and the articles.... one of the things that caused me anxiety as I left the court

was I wouldn't have access to that. It is exactly what I've found to be. You walk out into your private practice and you're completely without any of that support.... But over the years I've developed a personal network, so I've got lots of friends who still send me stuff and do it that way.

Nearly all of the participants seemed to be aware of the Australian Institute of Family Studies and its website full of information and publications - almost all available online. It is also apparent that there is a cohort of Australian social scientists and socio-legal scholars whose works are well known and whose names recurred throughout the focus groups, $^{61}$ for example, Jennifer McIntosh, ${ }^{62}$ Tom Altobelli, ${ }^{63}$ Richard Chisholm ${ }^{64}$ and

58 Murray Levine and Barbara Howe, 'The Penetration of Social Science into Legal Culture' (1985) 7 Law \& Policy 173, 190.

59 This finding is consistent with a recent UK stakeholder consultation on the use of social science in the family law system: Broadhurst et al, above n 2, 18-21, 60 .

60 More academic literature is becoming accessible online through new publishing platforms.

61 This suggests that lawyers and other professionals will go to what they already know and feel comfortable with - a manifestation of the availability heuristic. See Burns, above $\mathbf{n} 54$, 330-1.

62 Clinical psychologist, adjunct Professor at La Trobe University, Director of Family Transitions and prolific publisher.

63 Federal Circuit Court judge (and Federal Magistrate) since 2006. Prior to that he was Special Counsel to a family law practice and held the position of Associate Professor, School of Law, University of Western Sydney.

64 Adjunct Professor of Law at ANU College of Law, prolific publisher and former judge of the Family Court of Australia (1993-2004) and former legal academic. 
Patrick Parkinson. ${ }^{65}$ However, the data from the participants demonstrate that some practitioners in the family law system become familiar only with this shared slice of knowledge ${ }^{66}$ and have little opportunity or time ${ }^{67}$ to explore other ideas and opinions. ${ }^{68}$ It was also clear that other participants read quite widely and independently. Some were doing further studies in a range of areas, and others held dual law/social science qualifications.

\section{E How Judges Use Social Science Research in their Daily Courtroom Practice}

A critical aspect of this study was that the methodology employed allowed for exploration of the participants' perceptions of the practices of judges in court. This every day activity is invisible in the published judgments which provide the basis for formal jurisprudence. Although the discussion in the focus groups occasionally related to contested hearings, most of the stories were about what happens at mentions, directions hearings, interim 'hearings' 69 and before the commencement of a trial. The data shine a light on the areas of daily work of judges and other actors in the family law system. John Eekelaar and Mavis Maclean have examined this kind of every day judicial work in the United Kingdom. ${ }^{70}$ Those scholars identified three major roles played by judges in the actual work they did; legal activity, management and help (which includes facilitating settlements and discussing possible options with the parties). ${ }^{71}$ Our data suggest that Australian judges also perform these three roles and use social science research to assist in undertaking each of them.

It was generally accepted throughout the focus groups that social science literature was discussed in courtrooms by most of the professionals involved in parenting casesjudges, lawyers and expert witnesses. In terms of judges, focus group participants reported them referencing specific literature as well as unsourced 'research' during their conversations with parties about how a case might proceed or about specific social, medical or psychological matters relevant to that case. Some judicial officers were described as issuing a kind of unofficial set of directions about the distribution of, or

65 Professor, Sydney University School of Law and prolific researcher and publisher.

66 The UK Stakeholder consultation also showed that practitioners tended to be familiar with the same literature. In the UK there was particular reliance on the well-known family law journal-Family Law. See Broadhurst et al, above n 2, 16.

67 A number of participants spoke of the difficulty of finding time to read this kind of literature as well as everything else they need to keep to up to date with as family lawyers. There were similar findings in the UK Stakeholder consultation. See Broadhurst et al, above n 2, 18-19.

68 This raises interesting questions about the operation of unconscious biases and heuristics in human decision-making-which apply to judges and all other professionals in the family law system. See Burns, above $n 54$.

69 Which are conducted 'on the papers' in the absence of any oral evidence.

70 John Eekelaar and Mavis Maclean, Family Justice: The Work of Family Judges in Uncertain Times (Hart Publishing, 2013).

71 Ibid 79-80. Empirical studies of the daily work of judges of the lower courts in Australia have been undertaken by Kathy Mack and colleagues over a number of years. See Sharyn Roach Anleu and Kathy Mack, Performing Judicial Authority in the Lower Courts (Palgrave, 2017); Kathy Mack, Anne Wallace and Sharyn Roach Anleu, Judicial Workload: Time, Tasks and Work Organisation (Australasian Institute of Judicial Administration, 2012). 
engagement with, social science literature. ${ }^{72}$ These 'directions' were quite varied and included:

- directing that particular articles be made available to the solicitors in the case for reading by their clients;

- directing that specific literature be issued to all parties in the proceedings;

- directing that specific material be sent to the family report writer ${ }^{73}$ - often by the independent children's lawyer (ICL), but sometimes by a solicitor for a party; and

- requesting the ICL to ask the family report writer 'to comment in her material on the attachment theories and the recent research into developmental and age appropriate contacts. ${ }^{.74}$

Topics that focus group participants mentioned as being covered in the literature referred to by judges included shared care, family violence, attachment theory, breastfeeding and parental alienation. Many of the participants were actively reading some kind of social science literature themselves to understand more about what kind of postseparation arrangements work in particular families, and to learn about an array of complex social issues which they were dealing with in their client work; family and domestic violence, drug and alcohol misuse, mental health issues, children with special needs etc. They expected other professionals they worked with in the system to also have relevant knowledge. However, participants raised a number of concerns about social science research in the courtroom, particularly when it was only in the hands of judges and legal representatives and not expert witnesses.

There is an uneasy contradiction in these views. On the one hand professionals in the family law system want informed judges who can make meaningful decisions in complex family law cases involving children, but they raise valid concerns about judges employing social science literature as a courtroom tool. And yet Australia, and many other countries, provides judicial education to ensure that judges are well-informed, both about the law over which they preside and the non-legal issues which arise in their courts. Canadian barrister Marie Gordon has commented on the conflicting attitudes about judges and extraneous knowledge:

72 A form of judicial 'management' in the Eekelaar and Maclean characterisation. See Eekelaar and Maclean, above $n$ 70, 79 .

73 A 'family report writer' (more correctly called a 'family consultant' now) in Australian family law is a social scientist (a social worker or psychologist) who is brought into parenting proceedings to provide a report to the court about the family, the breakdown, the individuals affected by the dispute and suggestions or recommendations for the future. The reports are influential documents, partly due to the perceived independent or neutral status of the writer. See Rachael Field et al, 'Family Reports and Family Violence in Australian Family Law Proceedings: What Do We Know?' (2016) 25 Journal of Judicial Administration 212.

74 A lawyer focus group participant describing what one judge requested. This probably falls within s $62 \mathrm{G}(2)$ of the Act which says: ' $\mathrm{t}$ ] he court may direct a family consultant to give the court a report on such matters relevant to the proceedings as the court thinks desirable'. 
it seems contradictory to encourage judges to incorporate understandings of non-legal topics germane to their findings, and then criticise them when they use this knowledge to come to more informed outcomes in family proceedings!. ${ }^{75}$

Focus group participants were also alert to the irony of this balancing act. As one lawyer said about judicial education and training:

They're all being taught and they're all being lectured on this research, what are the theories behind some of this - they're all actually getting independent education through their own conferences, and the courts are calling people in. So, they've got all this information, they've got it all and they're bright people.

They have got to plug in somewhere. They get all this information, but when they walk into a courtroom, they have to deal with the evidence that is produced in front of them, and what is not being produced is that bit. So, they've got the information, everyone was critical of them for not knowing anything about this stuff-you don't understand it. They get them educated, and then that evidence isn't presented. ...

But when they've got to do a judgment, it's got to be based on the evidence.

Bearing this contradiction in mind, it is instructive to consider the main concerns of the focus group participants regarding judicial use of social science research during proceedings.

\section{F Concerns about Judicial Use of Social Science}

The reasons why participants were concerned about judges bringing the research into the courtroom tended to reflect many of the concerns raised in the literature on social science and law and in the cases:

- natural justice must be accorded to the parties and the judge must identify material being used;

- often no source is identified;

- $\quad$ social science is contested and changeable;

- judges have inadequate skills in and understanding of how to use social science research; and

- using social science in court risks inappropriately applying the general to the particular.

These will each be briefly discussed.

1 Natural Justice Must be Accorded to the Parties and the Judge Must Identify Material being Used

Natural justice was an issue that arose in a number of the appellate cases that occurred around the time of the focus groups. These cases involved situations where trial judges

75 Marie Gordon, 'Infants and Toddlers: Furthering Our Collective Understanding of Their Needs in Post-Separation Parenting Plans' (Paper presented at $6^{\text {th }}$ World Congress on Family Law and Children's Rights, Sydney, 2013) 36. Nevertheless, she had concerns about the way in which some judges were harnessing the literature and the tendency for a smallish group of scholars to become prevalent in the cases. Australian commentary about judicial education includes: Justice J Allsop, 'Continuing Judicial Education: The Australian Experience' (Paper presented at the International Forum on Judicial Training, National Judges College of China, Beijing, 8-10 June 2011); Shellee Wakefield and Annabel Taylor, 'Judicial Education for Domestic and Family Violence (State of Knowledge Paper, Australia's National Research Organisation for Women's Safety Limited, June 2015). 
had cited social science research in their reasons for judgment without having notified the parties of an intention to do so. ${ }^{76}$ The term 'natural justice' was only used by one focus group participant, although the discussions about the contested nature of social science and the extent to which judicial notice could be taken of social science propositions implied that the participants generally considered that judges should give notice of any social science research to be cited. The direct comment about natural justice was consistent with the general tenor of Full Court opinion:

if they're going to be using social science theory or a piece of literature or whatever they

been reading, they need to identify it. ... So, there is a natural justice issue there ... (lawyer)

It was apparent from published decisions, including appeals, that judges did not always notify lawyers or their clients about the social science literature that would be referenced. This clearly raises concern for both lawyers and their clients, because it shuts down the opportunity to proffer research that takes a different view.

(a) Often No Source is Identified

Many focus group participants spoke of the way that social science ideas are brought into the courtroom by judges openly, but non-transparently-without identifying, or even acknowledging the existence of, a source. Expressions are used such as: 'the research says', 'the experts say' and 'what we know is' to introduce a brief summary of their version of the social science literature relevant to the case before them.

For example, in a case involving a young baby, one lawyer participant reported that a judicial officer said:

look, I am not going to make these orders, because all of the research is showing that if I take this child away from her primary carer, it is going to do terrible damage. You sit there

thinking, God, that's so appealable ...77

That may be right; however, the appellate decisions around this issue have generally occurred in cases where specific social science has been cited, rather than when a judge has made mention of unreferenced research. This general referencing of 'research' is not a new judicial practice. As noted previously, Mullane found that $5 \%$ of the findings of social fact were from unsourced 'research'. ${ }^{78}$ However, such comments may well be disconcerting to the litigants, a point made in a number of the appellate decisions. ${ }^{79}$

Some participants noted that judges referred to unreferenced material as a way of encouraging settlement in some cases. ${ }^{80}$ Focus group participants reported that one piece of 'research' frequently used by judges with the parties is the idea that ongoing

76 Allen v Green (2010) 42 Fam LR 538; Baranski v Baranski (2012) 259 FLR 122; McGregor (2012) 47 Fam LR 498.

77 This could be considered 'legal activity' on the Eekelaar and Maclean categorisation - but it demonstrates how involved social science can be in legal decision-making. See Eekelaar and Maclean, above $n 70,79$.

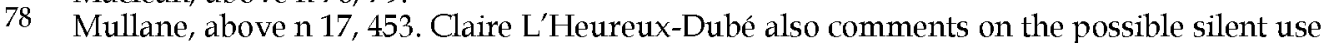
of social science research by judges if the rules of judicial notice are too strict. See Claire L'Heureux-Dubé, 'Re-Examining the Doctrine of Judicial Notice in the Family Law Context' (1994) 26 Ottawa Law Review 551, 558.

79 Dylan v Dylan [2007] FamCA 842 (21 August 2007) [2]; SCVG v KLD [2011] FamCAFC 100 (6 May 2011) [56]; Baranski v Baranski (2012) 259 FLR 122 [154].

80 This is the 'helping' work of judges as described by Eekelaar and Maclean-although they made no observations about the use of 'research' in any form. See Eekelaar and Maclean, above $\mathbf{n} 70$. 
conflict between parents post-separation is detrimental to their children - so they should try to settle the matter. As one lawyer explained:

I think one of the most regular examples is where you get judges, particularly through the Magistrates Court, ${ }^{81}$ directly talking to the litigants just before it boots on into a fully blown trial, where they invite them - do you know what you're doing, all the literature tells us about parents who fight, and do you know how this will affect your child? In the most generic sense, that's how I see the bench of its own initiation [sic] bringing in, and it talks in terms of that effect on a child and what the literature says about, you know ... parents fighting and things like that.

It was reported that judicial officers also made statements about 'research' relevant to other matters in a case, such as parenting time for very young children or concerns about parental alienation. Such statements from the lips of the judicial officer would obviously be influential in settlement negotiations.

(b) Social Science is Contested and Changeable

Focus group participants were also acutely aware of the contested nature of social science and the complicated consequences of that. ${ }^{82}$ They discussed this both in terms of keeping up with social science themselves and also what it meant when social science research is used by judges. A comment by one participant highlighted the difficulties faced by lawyers:

But as a lawyer, I don't want to go around reading a thousand reports. I don't want to go around kind of-well, last week, it was this theory, and this week it's this theory, and next week well they're researching this.

At the time of the focus groups a debate about overnight visits, shared postseparation care and infants had begun to emerge among Australian researchers. Many of the researchers well known to the focus group participants were involved. It arose out of differing interpretations of the impact of the 2006 amendments in a number of evaluative reports and publications. ${ }^{83}$ By 2011 the debate had become quite vigorous and number of articles were published in an edition of the Australian Journal of Family Law. ${ }^{84}$ Unsurprisingly these disagreements were well known amongst our focus group participants. As one lawyer said during a discussion about shared care and infants: '[s]ee that's the trouble. The social science isn't consistent'. The focus group discussions proved prescient. By 2014 the issue of shared care and young children, and the

81 Ie Federal Magistrates Court of Australia, now the Federal Circuit Court of Australia.

82 This was also noted by the participants in the UK study. See Broadhurst et al, above n 2, 21.

83 Jennifer McIntosh et al, 'Post-separation Parenting Arrangements and Developmental Outcomes for Infants and Children - Collected Reports' (Collected Reports, Family Transitions, May 2010); J Cashmore et al, 'Shared Care Parenting Arrangements since the 2006 Family Law Reforms' (Report, Social Policy Research Centre, University of New South Wales, May 2010)

<https://www.ag.gov.au/Families AndMarriage/Families/FamilyLawSystem/Documents /SharedCareParenting Arrangementssincethe2006FamilyLawreformsreport.PDF>.

84 See Judy Cashmore and Patrick Parkinson, 'Parenting Arrangements for Young Children: Messages from Research' (2011) 25 Australian Joumal of Family Law 236; the comment that followed: Bruce Smyth, Jennifer McIntosh and Margaret Kelaher, 'Research into Parenting Arrangements for Young Children: Comment on Cashmore and Parkinson' (2011) 25 Australian Journal of Family Law 258; and the response to the comment: Patrick Parkinson and Judy Cashmore, 'Parenting Arrangements for Young Children - A Reply to Smyth, McIntosh and Kelaher' (2011) 25 Australian Journal of Family Law 284. 
presentation of research literature about it in parenting litigation, had become a matter of international consternation. ${ }^{85}$ Hotly debated theories can inhibit judicial comfort with ideas. In one case involving a three year old boy with a diagnosis of Autism Spectrum Disorder, a presiding judge complained that he had not been provided with any research to support a family report writer's discussion about 'infants and young children and their attachments and sense of time'. ${ }^{86}$ His Honour went on to say that his 'understanding of the field is that relevant social theory is a dynamic and at times controversial field' and footnoted the 'recent debate ... between Professor McIntosh and her American colleague, Richard A Warshak' ${ }^{\prime 87}$ Consequently, he found that he could not accept the report writer's conclusions that the boy should live with his mother and spend five days per fortnight with his father. Instead he made an order for equal time.

The fluid and mutable nature of social science, exemplified by this debate, shows how difficult it would be for a social science concept to attain the status of knowledge that could be judicially noticed - that is, "knowledge that is not reasonably open to question' ${ }^{88}$ However, in two focus groups the example of 'attachment theory' was proffered by participants as a social science which was (almost) judicially noticed in their litigation experience. One experienced lawyer commented that the idea of 'primary attachment' had been treated almost as judicial notice throughout all her of years of practice - more than 25 years. She also said it went out of fashion for a while, ${ }^{89}$ but it was clear from her comments and other focus group participants that it was now back in the courtroom discussion. Another lawyer participant remarked:

So this attachment theory thing has been building up consistently for about three years all going in the same-everyone I hear speak about it is going in the same direction okay.

The data from the mapping history project suggests that encouragement of shared parenting through the amendments to the Act may partly explain the perceived reemergence of talk about attachment theory at the time of the focus groups. ${ }^{90}$ Equal or substantially shared care time post-separation parenting arrangements had not been a favoured option in Australian family courts, ${ }^{91}$ but these concepts were legislated in 2006. Understanding attachment theory, therefore, became critical to decision-making in cases with infants, to determine how infants might fare if separated from their

85 See Warshak, above n 2; Linda Nielsen, 'Woozles: Their Role in Custody Law Reform, Parenting Plans, and Family Court' (2014) 20 Psychology, Public Policy, and Law 164; Jennifer E McIntosh, Bruce M Smyth and Margaret A Kelaher, 'Responding to Concerns about a Study of Infant Overnight Care Postseparation, with Comments on Consensus: Reply to Warshak (2014)' (2015) 21 Psychology, Public Policy, and Law 111.

86 Tyers \& Stafford [2014] FCCA 480 (5 June 2014) [71]

87 Ibid [72].

88 Evidence Act 1995 (Cth) s 144(1)

89 This may have been when concern about children not spending enough time with separated fathers dominated public discussion about family law. When the Prime Minister, John Howard MP, announced the Inquiry into 'custody' law in 2003 he expressed concern that 'too many boys are growing up without proper role models': Phillip Hudson, 'PM Orders Inquiry on Joint Custody', The Age (Melbourne), 25 June 2003.

90 Rathus, 'Mapping the Use of Social Science', above n 1, 369.

91 House of Representatives Standing Committee on Family and Community Affairs, Parliament of Australia, Every Picture Tells a Story: Report on the Inquiry into Child Custody Arrangements in the Event of Family Separation (2003). 
'primary carer' for extended periods. ${ }^{92}$ Whether judicial notice can be taken of that idea remains unclear.

2 Judges Have Inadequate Skills in and Understanding of How to Use Social Science Research

A number of lawyer participants made the point that the only legally correct way of ensuring that social scientific material becomes part of the information before a court is through an expert witness. In that instance questions can be put to an expert witness about the material - either with or without tendering it. One blunt exchange between a barrister and a solicitor during a focus group revealed the barrister's frustration about how Benjamin J handled social science literature about family violence in Maluka $v$ Maluka: ${ }^{93}$

Solicitor: I don't know how much more Justice Benjamin could have done under section 144 [Evidence Act 1995 (Cth)] ... to get that stuff in.

Barrister: He could have put it to the expert for a start.

Solicitor: Well I suppose so, but I mean ...

Barrister: Pretty basic- he didn't ...

One social science participant aired her concerns about social science research in the hands of judges who are generally not trained to assess scientific methodology or quality:

I feel sometimes that judges and so on are using the social science without a great understanding of it behind it at all because they're not trained in that area. They pick up an article and say this sounds really great. Let's use this and let's go this way. That really concerns me that they've got no training in this area, they've got no understanding, no psychology training or anything like that. Then, they're using that research, which may not be the best research out there.

This issue is considered in some academic work, ${ }^{94}$ but received no attention in the family law appellate decisions about judicial use of social science literature. Heydon J acknowledged this problem in Aytugrul $v$ The Queen, ${ }^{95}$ a High Court of Australia authority on the use of published research in the criminal courts, which was decided just before the Full Court of the Family Court determined McGregor: ${ }^{96}$ ' $[\mathrm{t}$ ]o borrow the words of Judge Frank speaking about psychiatry, it would be dangerous for the Court "to

92 The mapping data suggest that one of the gaps in law judges sought to fill after the 2006 amendments was the relevance of age to considering equal or substantial and significant time parenting orders. Rathus, 'Mapping the Use of Social Science', above n 1, 370-1.

93 (2011) 45 Fam LR 129, on appeal from Maluka v Maluka [2009] FamCA 647 (24 July 2009).

94 See generally Alice Bailey, 'Separating Safety from Situational Violence: Response to Allegations of Family Violence and Child Abuse in Family Law Children's Proceedings: A Pre-Reform Exploratory Study' (2007) 77 Family Matters 26; Jane Wangmann, 'Different Types of Intimate Partner Violence? A Comment on the Australian Institute of Family Studies Report Examining Allegations of Family Violence in Child Proceedings under the Family Law Act' (2008) 22 Australian Joumal of Family Law 123; Tom Altobelli, 'Family Violence and Parenting: Future Directions in Practice' (2009) 23 Australian Journal of Family Law 194; L'Heureux-Dubé, above $n 78$.

95 (2012) 247 CLR 170.

96 (2012) 47 Fam LR 498. The case is not referred to in McGregor. 
embark - without a pilot, rudder, compass or radar - on an amateur's voyage on [this] fog-enshrouded sea"'.97

3 Using Social Science in Court Risks Applying the General to the Particular

Focus group participants also spoke of the problem that social science research provided generalities - what was most likely, or what were common features of some condition or issue-whereas the job of a judge is to decide the case before them. One lawyer explained how a new judge was 'very into the Jennifer McIntosh attachment theory' and said that 'it was concerning that the judge kept referring to the same piece of information for every matter that seemed to come before her'. Another lawyer in the same group continued the theme:

That's the thing you've got to remember. So much of the research says these are general trends, each matter can be different. ...

Jenny [McIntosh] is the first one to say, you've got to look at each case individually and that's what worries me, is that sometimes they go this is the research that applies to this case without really looking into-a lot of people hear about the research without really looking into it. Who's got time to look into everything that it says and apply it to that case? It becomes dangerous.

In the context of noting that 'we are seeing more and more [social science literature] in judgments and in reports', 98 a lawyer in a different group also noted the problem of applying general findings to the particular case and used the example of McIntosh's work:

it's a general, qualitative piece of information and research that she's done, but it's not about the family that's in front of that judge.

Peter Jaffe, who has worked at the intersection of social science and family law for many years, has observed that it is a matter of 'longstanding concern' that courts and those working in the courts 'often apply the research findings from studies of community samples to a totally different population engaged in litigation in the family justice system' ${ }^{\prime 99}$ But the issue is quite nuanced: while some commentators point out the difference between the law and science - the rule based paradigm of the law and the tentative and exploratory nature of science ${ }^{100}$ - others have noted the similarity. L'Heureux-Dubé drew on the work of John Monahan and Laurens Walker ${ }^{101}$ to conclude that 'one of the greatest similarities between social science research or data and

97 United States v Flores-Rodriguez 237 F 2d 405, 412 (Frank J) (2nd Cir, 1956), quoted in Aytugrul $v$ The Queen (2012) 247 CLR 170, 203 [74].

98 Referring to family reports and expert reports. The suggestion that family report writers use social science was later contradicted by the participants in that focus group, including the participant who said this, agreeing that it is very hard to get family report writers to cite social science literature.

99 Peter Jaffe, 'A Presumption against Shared Parenting for Family Court Litigants' (2014) 52 Family Court Review 187, 188.

100 This view was taken by Susan Haack in 'Trials and Tribulations: Science in the Courts' (2003) 132 Daedalus 54.

101 These two scholars have written about the intersection of science and law for many years. See generally John Monahan and Laurens Walker, 'Social Authority: Obtaining, Evaluating, and Establishing Social Science in Law' (1986) 134 University of Pennsylvania Law Review 477; Walker and Monahan, 'Social Frameworks', above n 4; John Monahan and Laurens Walker, 'Twenty-Five Years of Social Science in Law' (2011) 35 Law and Human Behaviour 72. 
legal principles is their generality'. ${ }^{102}$ Perhaps that is why lawyers seem to feel comfortable wielding terms and tools-it is somehow familiar-and this can be misleading.

\section{G How Legal Practitioners Use Social Science}

The focus groups identified a number of ways in which lawyers use social science research in their work:

- to educate clients

- as a reality check

- in strategically drafting documents

- in making submissions

- in cross-examining expert witnesses

Each of these will be addressed in turn.

1 Educating Clients and Reality Checking

Legal practitioners reported gathering social science literature and, as part of providing a full service, giving clients materials which were relevant to their particular situation. Such materials also educated clients about concepts that might be useful for them to consider. Some solicitors have a set of materials they frequently provide, while others provide information especially tailored to the needs of particular clients and others simply refer to social science in discussions with their clients. It appears that social science research-whether provided in written form or just described orally to the client-is used by lawyers as a way of assisting clients to understand the reasonable parameters of their case. In other words, clients may sometimes be persuaded towards a more likely court outcome, and away from an extreme position, by discussing social science research. One lawyer participant said that the key was that the client should be seeking 'realistic outcomes', and another added:

Yeah and I think too that's the expectation of the court. In fact they take a very dim view of the way we've managed a matter if our clients have unrealistic expectations. We're likely to get our arses kicked fairly solidly.

As discussed, participants also talked about judges' use of social science research as a reality check with litigants and as a tool to encourage settlement. Additionally, social scientists described using the research to assist clients to be realistic - and using the law in much the same way - to keep the clients within sensible boundaries.

\section{Strategically Drafting Documents and Developing Submissions}

Some of the use of social science by legal practitioners is quite strategic and relates to how they prepare documents and present their cases. Of course, presenting a case in a way that aligns with social science literature is good lawyering and is likely to be consistent with the paramount principle of the best interests of the child.

A neat example of bringing together social science, the law and drafting was provided by a lawyer who was musing over the new definition of family violence in the Act which had become operative in 2012, at about the time of the focus groups in that

102 L'Heureux-Dubé, above $n 78,566$. She also noted that the dissimilarities meant that social science studies yield general results, often drawn from a specific sample, whereas a judge must decide the case before her: at 565 . 
year. ${ }^{103}$ To some extent the definition mirrors some of the language in the well-known American 'typology' literature on domestic and family violence. ${ }^{104}$ One version of the typology theories holds that there are four types of family violence: 'coercive controlling violence', 'violent resistance', 'separation-instigated violence' and 'situational couple violence'. ${ }^{105}$ The definition contains the words 'coerces or controls', and the next subsection contains a long list of examples which 'may constitute family violence'. However, the examples are not technically part of the definition. The definition is only contained in $\mathrm{S} 4 \mathrm{AB}(1)$ which says:

family violence means violent, threatening or other behaviour by a person that coerces or controls a member of the person's family (the family member), or causes the family member to be fearful.

The examples include assault, sexual assault, stalking, repeated derogatory taunts, property damage, pet abuse, financial abuse and social and familial isolation. ${ }^{106}$

It has been argued that this definition seems to work in two opposing ways; on the one hand it requires that violence must coerce or control a family member, or cause them to be fearful-arguably creating a narrow definition by excluding other types of family violence. ${ }^{107}$ On the other hand, the list of examples encourages people to narrate stories of emotional, financial and psychological abuse that may not have been described in their filed material prior to the amendments - arguably constructing a broad definition. Research conducted since the reforms suggests that litigants are including a wider range

$103 \mathrm{~S} 4 \mathrm{AB}$ of the Act which became operative through the Family Law Legislation Amendment (Family Violence and Other Measures) Act 2011 (Cth) in June 2012, shortly before the focus groups were held.

104 There are many scholarly works about typologies of family violence but one has become particularly well known in the Australian family law community. Some of it is cited in the Family Violence Best Practice Principles. See generally Joan B Kelly and Michael P Johnson, 'Differentiation among Types of Intimate Partner Violence: Research Update and Implications for Interventions' (2008) 46 Family Court Review 476; Michael P Johnson and Kathleen J Ferraro, 'Research on Domestic Violence in the 1990s: Making Distinctions' (2000) 62 Journal of Marriage and the Family 948; Ellen Pence and Shamita Das Dasgupta, ReExamining 'Battering': Are All Acts of Violence against Intimate Partners the Same? (June 20 2006) Praxis International, 5-14 <http://praxisinternational.org/wpcontent/uploads/2016/02/ReexaminingBattering-1.pdf>; Janet R Johnston and Linda E G Campbell, 'A Clinical Typology of Interparental Violence in Disputed-Custody Divorces' (1993) 63 American Journal of Orthopsychiatry 190.

105 Kelly and Johnson, above $\mathrm{n} 104$. This literature has been the subject of some academic debate in Australia. See generally Zoe Rathus, 'Shifting Language and Meanings Between Social Science and the Law: Defining Family Violence' (2013) 36 University of New South Wales Law Journal 359; Jane Wangmann, 'Different Types of Intimate Partner Violence - An Exploration of the Literature' (Issues Paper No 22, Australian Domestic \& Family Violence Clearinghouse, October 2011); Lawrence Moloney et al, 'Different Types of Intimate Partner Violence? Reply to Wangmann's Comments on the AIFS Report' (2008) 22 Australian Journal of Family Law 279; Richard Chisholm has also noted '[t]he potential risk ... that we might come to think that every instance of family violence will fit within one category or another ...': Richard Chisholm, Attorney General's Department (Cth), Family Courts Violence Review (27 November 2009) 38 <https://www.ag.gov.au/FamiliesAndMarriage/Families/FamilyViolence/Documents/F amily\%20Courts\%20Violence\% 20 Review.doc $>$.

106 Act s $4 \mathrm{AB}(2)$.

107 Rathus, 'Shifting Language and Meanings', above n 105. 
of abusive behaviour in their affidavits, ${ }^{108}$ but that some judges look to ascertain whether the abuse described amounts to coercive control or whether it may be one of the other types, and therefore not quite family violence. ${ }^{109}$

The focus group lawyer implicitly invoked the typology literature to explain how she thought about drafting affidavits since the amendments. ${ }^{110}$ In her view, the new definition allowed for a broader range of behaviour to be described in her clients' affidavits. She said:

it makes you think about whether it was situational violence, or whether it has been coercive and controlling violence; you know, whether it has been, there has been a pattern of abuse throughout the relationship and at the end of the relationship, it was getting worse.

In terms of the presentation of cases-whether drafting material or making submissions - one barrister commented on the importance of attending conferences and keeping abreast of the social science that is in vogue:

I can gauge which way it's ${ }^{111}$ turning by what's being presented. I try to go to as many of those [seminars and conferences] as I can.

Another lawyer reported always being aware of which judges attended the same conferences, and even the same sessions as she did. She could then shape submissions in cases before those judges to incorporate social science ideas she knows that judge has heard. But even if the judge does not share knowledge with the legal representative, submissions drawing on relevant research are still viable. One lawyer participant reported that she incorporated some ideas from a social science seminar about childhood brain development which she had attended one weekend, into submissions she made on the following Monday. The judge had not been present but listened with interest.

3 Cross-Examining Experts

A number of the lawyer participants discussed using social science research to challenge expert witnesses - or to elucidate a point of expert testimony that was important to their case. The social science qualified participants who had been cross-examined as expert witnesses suggested that barristers seemed to be skilled at targeting controversial areas of social science, such as the concept of 'parental alienation syndrome' as described by

108 Pam Hemphill, 'On the Crest of a Wave: the Australian Family Violence Reforms One Year Later' (Paper presented at Association of Family and Conciliation Courts $50^{\text {th }}$ Annual Conference, Los Angeles, California, 1 June 2013); Justice Steven Strickland and Kristen Murray 'A Judicial Perspective on the Australian Family Violence Reforms 12 Months On' (2014) 28 Australian Journal of Family Law 47; Rae Kaspiew et al, 'Evaluation of the 2012 Family Violence Amendments: Synthesis Report' (Synthesis Report, Australian Institute of Family Studies, October 2015) <https:/ /aifs.gov.au/publications/evaluation-2012-family-violenceamendments/acknowledgements>

109 See Rathus, 'Shifting Language and Meanings', above n 105; Jane Wangmann, 'Different Types of Intimate Partner Violence-What do Family Law Decisions Reveal?' (2016) 30 Australian Joumal of Family Law 77.

110 The use of this literature in the courtroom is an issue of concern to a number of researchers who have observed that this contributes to a situation where only serious physical violence is rendered relevant to parenting outcomes. See Joan S Meier, 'Dangerous Liaisons: Social Science and Law in Domestic Violence Cases' (2017) 13(51) Women, Gender and the Law eJournal; Wangmann,'Different Types of Intimate Partner Violence - What do Family Law Decisions Reveal?', above $\mathrm{n} 109$.

111 Perhaps the best way to describe what the focus participant was referring to here is to saythe attitude of the family law practice community -including judges. 
Richard Gardner. ${ }^{112}$ This work has been widely criticised in the literature, ${ }^{113}$ and in cases, ${ }^{114}$ and the discrediting of the concept was noted in both lawyer and non-lawyer focus groups. For example, one non-lawyer said:

We all know about the fabled parental alienation literature. That still gets drawn on, so

there's a discredited piece of research...

But despite this concern about the literature and the contested social scientific views about parental alienation, the allegation that one parent has influenced the children against the other parent is a live issue in many litigated cases. ${ }^{115}$ Therefore, expert witnesses will be required to address the concept of parental alienation in reports and oral evidence in many cases, and consequently will be open to cross-examination in this disputed field.

\section{H How Social Scientists Use Social Science Research}

The social scientists' reports about how they use social science literature were intriguing. Some of the social science participants described using the research to inform their practices and educate their clients. But surprisingly, a number of participants in lawyer focus groups reported that the group of professionals who most tended to eschew referencing social science literature were the social scientists themselves - the expert witnesses (including family report writers), charged with providing the court with their opinion based on their social science expertise.

In terms of using the research directly in client work one social science participant explained that she liked to keep abreast of the practice oriented research so that she can learn about new ideas and continue to enhance her practice methods. Another explained how she uses social science to 'normalise' situations for clients (eg what is happening in your family is not unusual -it is part of the growing process of adolescents etc). This can assist a client to deal with their own situation, but it can also be part of encouraging realistic thinking (and perhaps moving a client towards a settlement)-mirroring how some lawyers use social science as a reality checker with their clients.

112 See Richard Gardner, Child Custody Litigation: A Guide for Parents and Mental Health Professionals (Creative Therapeutics, $1^{\text {st }}$ ed, 1986); Richard A. Gardner, 'The Judiciary's Role in the Etiology, Symptom Development, and Treatment of the Parental Alienation Syndrome (PAS)' (2003) 21 American Journal of Forensic Psychology 39.

113 See generally, Joan S Meier, 'A Historical Perspective on Parental Alienation Syndrome and Parental Alienation' (2009) 6 Journal of Child Custody 232; Carol S Bruch, 'Parental Alienation Syndrome and Parental Alienation: Getting it Wrong in Child Custody Cases' (2001) 35 Family Law Quarterly 527; Cheri L Wood, 'The Parental Alienation Syndrome: A Dangerous Aura of Reliability' (1994) 27 Loyola of Los Angeles Law Review 1367; Jennifer Hoult, 'The Evidentiary Admissibility of Parental Alienation Syndrome: Science, Law, and Policy' (2006) 26(1) Children's Legal Rights Journal 1; Joan B Kelly and Janet R Johnston, 'The Alienated Child: A Reformulation of Parental Alienation Syndrome' (2001) 39 Family Court Review 249.

114 See, eg, Irish v Michelle [2009] FamCA 66 (6 February 2009) [78] (Benjamin J): '[t]he research of Dr Johnston [Janet Johnston who is an American researcher who writes about parenting after separation] and others is widely accepted in Australia and Dr Gardner's PAS has been widely discredited'.

115 Nicholas Bala, 'Parental Alienation, Contact Problems and the Family Justice System', (20 February 2012) Australian Institute of Family Studies $<$ https://aifs.gov.au/sites/default/files/parental_alienation_contact_problems_and the_f amily_justice_system.pdf>. 
Social scientists also use the literature strategically to add kudos or veracity to their opinion if they are under challenge. One participant who sometimes gives expert testimony explained: 'particularly if you've got that resistance to something you're saying, then it's kind of like I need to bring the big guns out. The big guns will mean actually citing something ...'.

However, as noted, a number of participants reported that some social scientists seemed reluctant to cite the literature. As one lawyer said:

They'll often say ... the research indicates and then give us generalisations that they're basing their recommendations on. ... But not the research is specifically this or specifically that. So it's a matter of -it's almost perhaps kind of like there's a cloak. 'We're the experts, you don't have to know that' kind of feeling sometimes.

The phenomenon of expert witnesses assuming their knowledge base flows with their qualifications has been described by Timothy Tippins and Jeffrey Wittman:

clinicians arrive at court cloaked in the presumed objectivity of behavioral science when many subjective values are directing their conclusions (eg, boys do best with their fathers, children do best with their primary attachment figure, joint plans are bad for young children, etc). Few clinicians are up front with the legal consumers of their reports about the degree to which the assumptive underpinnings of their recommendations are highly subjective and controversial. ${ }^{116}$

Giving credence to this view, the focus group data indicate that some expert witnesses maintain the attitude that, as a qualified clinician/social worker/psychologist they do not need to go beyond their own expertise. In making recommendations about the family's future they do not need to support their opinions with academic literature. One barrister participant remarked that some expert witnesses were offended at the suggestion that citing social science 'could be helpful' or 'could justify something'. The participant cited an example of a social worker she had cross-examined who had not cited anything -'which wasn't unusual':

I asked him some questions, I said-because his recommendation just flew in the face of what I understand attachment theory to be, and I was asking him some questions and asking, can you tell me where do you get that from? Couldn't tell me and wouldn't-just was quite affronted.

Reported decisions reveal cases where judges have been frustrated by the lack of reference to social science by social scientists, ${ }_{117}$ and others where the research cited by family report writers was appreciated and adopted by the judge. ${ }^{118}$ However, the fact that literature is not cited does not necessarily mean that a witness is not familiar with it. A social science participant who has reviewed expert reports for clients explained that sometimes it was obvious that certain literature had informed a report, but a lack of proper referencing inhibited transparency and hindered the ability to appraise the findings:

It's not to say that in those family reports there wasn't language used from the literature.

There often was, but ... there would be no underpinning evidence to say why you might

116 Timothy M Tippins and Jeffrey P Wittman, 'Empirical and Ethical Problems with Custody Recommendations: A Call for Clinical Humility and Judicial Vigilance' (2005) 43 Family Court Review 193, 204.

117 See Benelong v Elias [2009] FamCA 1312 (31 December 2009) [69].

118 See Nettle v Nada [2013] FCCA 1677 (31 October 2013). 
choose that particular language to speak about a situation, ... but they're not being specific and, therefore, you can't critique in the same way.

Participants made some insightful observations about the consequences of social scientists not citing the research behind their thinking. One lawyer remarked: 'Well, they're not showing their workings'.

Identifying research relied on accords with good practice as described by Robert Simon and Philip Stahl, scholars and clinicians who study the quality of forensic reports in the USA. Although making the point in relation to the whole of the data in a family report rather than just literature cited, Robert Simon and Philip Stahl say that family report writers need to show their workings, comparing it to school teachers telling pupils to show their workings in mathematics problems. ${ }^{119}$

In 2014, after the focus groups had concluded, the family courts published a set of Assessment Standards for family report writers. ${ }^{120}$ The Standards drew on a number of existing guidelines from Australia and overseas, 121 and were also the product of extensive consultation. ${ }^{122}$ They state that family assessors:

are expected to have a broad knowledge of the relevant published peer reviewed research relating to issues for families and children in family law matters. They are also expected to have an understanding of the diversity of this research and the views and findings expressed in it, how it relates to the cases they assess, and the limitations of research in this area. ${ }^{123}$

The Standards realistically acknowledge that it is 'neither possible, nor appropriate, to provide references in every report for all of the research that underpins the knowledge that a family assessor brings to an assessment, ${ }^{\prime}{ }^{124}$ but suggest that a family assessor may choose to cite relevant literature 'where there are specific issues in dispute and recent and relevant peer reviewed and published research on those issues' ${ }^{125}$ Further research on family and expert reports and the oral testimony of family consultants and expert witnesses would be required to determine whether the Standards have encouraged more referencing of social science research by social scientists.

\section{CONCLUSION}

By conducting focus groups with the different groups of professionals who operate in the family law system in Australia, this study has revealed information about daily

119 Robert A Simon and Philip M Stahl, 'Analysis in Child-Custody-Evaluation Reports: A Crucial Component' (2014) 48 Family Law Quarterly 35, 40. See also J Brasch, 'There is No Magic in a Family Report' 29th Annual Queensland Family Law Residential, (Gold Coast, 2014) 15.

120 Family Court of Australia, Federal Circuit Court of Australia and Family Court of Western Australia, Australian Standards of Practice for Family Assessments and Reporting, (2014).

121 See generally Association of Family and Conciliation Courts, Model Standards of Practice for Child Custody Evaluation (May 2006) Association of Family and Conciliation Courts <https://www.afccnet.org/Portals/0/ModelStdsChildCustodyEvalSept2006.pdf>; Family Court of Australia and Federal Circuit Court of Australia Family Violence Best Practice Principles (3rd ed), 2012.

122 Family Court of Australia, Federal Circuit Court of Australia and Family Court of Western Australia, above $n$ 121, 6 .

123 Ibid [33].

124 Ibid [33(a)].

125 Ibid. 
practices that has never previously been brought to light. It has revealed details and nuances undiscoverable by reading the published decisions. The animated and engaged discussion which occurred provided a deep slice into the world of family law and demonstrated the level of penetration of social science research literature and information into the culture of family law practice. ${ }^{126}$ This is important to understand given that social science research is being intentionally intertwined with judicial decision-making through bench books ${ }^{127}$ and other publications addressed to judges and other users of our courts. ${ }^{128}$ The study interrogated this reality, considering benefits and disadvantages. It also allowed consideration of the broader question of how judges should deal with 'outside' knowledge in a case. ${ }^{129}$

It is clear that social science research is everywhere throughout the family law system - and always has been. But perhaps over the last decade or so it has been used with more intention by an increasingly knowledgeable cohort of professionals willing and enthusiastic to be part of a multi-disciplinary culture of practice. Social science is an open and visible part of the practice framework of all practitioner groups. They use it as a reality check, a facilitator of settlements and a tool to assist in exercising professional judgment. This suggests that practitioners consider that the social science research they use aligns with the kinds of decisions that might be expected from the court. Also, both lawyers and social scientists endeavour to use their social science knowledge to strategic advantage - in drafting documents, making submissions and giving evidence. The somewhat surprising assertions that some social scientists were reluctant to cite literature (which presumably informed their opinions) raise questions about the training available to expert witnesses.

In terms of what was learned about how practitioners perceive judges use social science, it seems that, although most participants in our focus groups were comfortable about their own use, they were less comfortable with judges' use. While participants expect and respect informed discussion about social science issues in the courtroom, they were concerned about a number of issues. There has been some Australian research

126 The 'increasing depth of penetration of social science culture into legal culture' is discussed in Levine and Howe, above $\mathrm{n} 58,173$.

127 The Australasian Institute of Judicial Administration (AIJA) has recently developed a family violence bench book: Australasian Institute of Judicial Administration, National Domestic and Family Violence BenchBook (Australasian Institute of Judicial Administration, 2016), available online at <http://dfvbenchbook.aija.org.au/contents>. The Judicial Commission of New South Wales has developed Bench Books on civil trials, criminal trials, 'equality before the law', local courts and sentencing: Judicial Commission of New South Wales, Bench Books and Handbooks

<https://www.judcom.nsw.gov.au/category/publications/bench-books/>. The bench book 'Equality before the Law', for the Supreme Court of Western Australia, is over 600 pages long: Steering Committee, Equality Before the Law Bench Book (Department of the Attorney General, 2009), available online at

<http://www.supremecourt.wa.gov.au/files/equality_before_the_law_benchbook.pdf>.

128 See, eg, Family Violence Committee, Family Violence Best Practice Principles (Family Court of Australia and Federal Circuit Court of Australia, $4^{\text {th }}$ ed, 2016) available online at $<\mathrm{http}$ ://www.familycourt.gov.au/wps/wcm/connect/fcoaweb/reports-andpublications/publications/family+violence/family-violence-best-practice-principles>. le knowledge or information that did not form part of the evidence of the parties. 
into the ability of judges (and juries) to deal effectively with scientific evidence, ${ }^{130}$ and the unacknowledged biases and heuristics which may influence what a judge decides to read and how he interprets it, ${ }^{131}$ and this research suggests that care needs to be taken when judges turn to material that is beyond the evidence of the parties.

Although judges have bench books and other formal and informal sources of data to draw from, there is still no clear or accepted way for general information to be placed before a court except through an expert witness. Exactly how judges should use the social science provided in bench books and other judicial guides is not apparent. Are they required to show their workings and disclose the sources that lie behind their thinking? And what about judges who have been reading social science for many years and have accumulated knowledge over time? What do they say? It also seems that social science information is so ubiquitous in family law that lawyers think of it as part of their tool set. While in some ways this is a genuine demonstration of interdisciplinarity, it also suggests that lawyers could benefit by being aware that they are dealing with a discipline likely to be outside their expertise or skill-set.

It is suggested that some ways of redressing these issues would be to consider training and information on a range of matters for lawyers, such as: how to assess the quality of scientific research, how to understand statistics, how to read and research social science literature and how to avoid selective knowledge acquisition. There could also be more training for expert witnesses, and this would include best practice in terms of referencing research that supports particular reasoning. It is also recommended that further research be conducted in this field, consulting widely with practitioners - to update and enhance the existing results-and with judges. The purpose of the consultation would be to understand more about the ways in which social science research is actually used by the different professionals groups and to develop guidelines for judges, lawyers and expert witnesses regarding the use of such research in court proceedings.

130 David Hamer and Gary Edmond, 'Judicial Notice: Beyond Adversarialism and into the Exogenous Zone' (2016) 25 Griffith Law Review 291; Edmond, Hamer and Cunliffe, above $\mathrm{n}$ 3; Gary Edmond, 'Judging Facts: Managing Expert Knowledges in Legal Decision-Making' in Gary Edmond (ed), Expertise in Regulation and Law (Routledge, $1^{\text {st }}$ ed, 2004) 136-165.

131 Burns, above $\mathrm{n} 54$. 
